Sergii I. Azarov ${ }^{1}$, D. S., Senior Research Associate

ORCID ID 0000-0002-9951-8867e-mail: azarov@kinr.kiev.ua

Oleksii S. Zadunaj ${ }^{2}$, Head of the Center, Postgraduate

ORCID ID 0000-0001-8589-1604 e-mail:a.zadunaj@gmail.com

${ }^{1}$ Institute for Nuclear Research of NASU, Kyiv, Ukraine

${ }^{2}$ State Research Institute of Special Communications and Information Protection, Kyiv, Ukraine

\title{
MODELING OF EVOLUTION NONLINEAR ECOSYSTEM
}

\begin{abstract}
The term «synergy», introduced in scientific literature by G. Haken, means «joint action, selforganization, the special effects of the joint action in complex systems». Synergetics as a methodology considers irreversibility as a condition for the development of systems, and the "imbalance" of systems as an imperative of development, and this is its fundamental difference from cybernetics, from the theory of operations research and from the general theory of systems. Synergy is usually called mathematical dialectics. The theory of synergetics and the theory of selforganization, in contrast to dialectics, have a powerful formalization apparatus, a set of basic and derivative models, including in the form of differential equations in time derivatives of the second order, in the form of fractals with fractional dimension, hamiltonians, taking into account the prehistory and long memory, mathematical models taken from the theory of bifurcations. The purpose of synergetics - the identification of general ideas, general methods and general laws in various fields of natural science.

At the same time new concepts have been developing about dissipative structures generating under no equilibrium conditions as a result of the exchange of energy (and substance) with the environment when approaching the external energy to the material. This scientific direction was headed by I.R. Prigogine. Nonlinear Science opens up new possibilities in the study of the conduct of real complex dynamic ecosystems. Nonlinear dynamics is a new science studying the evolution of the real nonlinear ecosystems, where along with determinism appears dynamic chaos. Shows the role of mathematical modeling in the study of nonlinear ecologic systems. Evolutionary change in complex ecosystems due to the phenomenon of selforganization and are associated with a decrease in entropy, which is achieved by the increasing complexity of the structural organization of the ecosystem.
\end{abstract}

Keywords: synergetic; nonlinear dynamics; complex structures; self-organization ecosystems

\section{С.I. Азаров ${ }^{1}$, O.С. Задунай ${ }^{2}$}

${ }^{1}$ Інститут ядерних досліджень НАН України, м. Київ, Україна

${ }^{2}$ Державний науково-дослідний інститут спеціального зв'язку та захисту інформації, м. Київ, Україна

\section{МОДЕЛЮВАННЯ ЕВОЛЮЦЇ̈ НЕЛІНІЙНИХ ЕКОСИСТЕМ}

Анотація. Термін «синергетика», введений в наукову літературу Г. Хакеном, означає «спільна дія, самоорганізованість, особливий ефект від спільної дії в складних системах». Синергетика як методологія розглядає незворотність

(C) S.I. Azarov, O.S. Zadunaj, 2019 
як умову розвитку систем, а «нерівновагу» систем - як імператив розвитку, i изе їі корінна відмінність від кібернетики, від теорії дослідження операцій $i$ від загальної теоріі систем. Синергетику зазвичай називають математичною діалектикою. Теорія синергетики і теорія самоорганізації, на відміну від діалектики, мають потужний апарат формалізації, набір базових $i$ похідних моделей, у тому числі у вигляді диференціальних рівнянь в часткових похідних другого порядку, у формі фракталів з дробовою розмірністю, гамільтоніанів, шео враховують передісторію $і$ довгу пам'ять, математичних моделей, які взяті з теорї̈ біфуркацій. Мета синергетики виявлення загальних ідей, загальних методів $i$ загальних закономірностей в самих різних областях природознавства.

Одночасно розвивалися нові уявлення про дисипативні структури, що утворюються в нерівноважних умовах у результаті обміну енергією ( $і$ речовиною) $з$ навколишнім середовищем під час підведення зовнішньої енергї̈ до матеріалу. Цей науковий напрям очолив І.Р. Пригожин. Нелінійна наука відкриває нові можливості у вивченні поведінки реальних складних динамічних екосистем. Нелінійна динаміка - ие нова наука, щчо вивчає еволюиію реальних нелінійних екосистем, у яких поряд із детермінізмом з'являється динамічний хаос.

Ключові слова: синергетика; нелінійна динаміка; складні структури; самоорганізація екосистеми

\section{Вступ}

Характерною рисою сучасного етапу розвитку екологічної науки $є$ іï математизація. Це, насамперед, пов'язано 3 тим, що типи екосистем, які розглядаються в сучасній екологічній теорії, $є$ істотно більш розвиненими, що призводить до більш складних закономірностей функціонування i, зокрема, до можливостей катастрофічних змін i хаотичної поведінки. Зміни, що відбуваються в нестійких динамічних екосистемах, можуть бути зрозумілі або осмислені тільки за допомогою математики і знаходяться за межами наших інтуїтивних уявлень. У дослідженнях з нелінійної динаміки показано [1], що малі зрушення параметрів можуть приводити до структурних змін динамічних систем. Складно організовані просторові, часові або просторово-часові структури можуть виникати 3 хаотичних станів, і в таких самоорганізованих системах виявляються еволюційні процеси, що приводять до ще більшого розмаїття і ускладнення структур [2]. Для розглянутих нелінійних екосистем характерні складні явища, такі як регулярні коливання і хаос. Навіть у відносно простих нелінійних динамічних екосистемах може спостерігатися спонтанне утворення складно організованих структур.

Принципово новий напрям у розвитку екологічної науки полягає у відмові від класичних уявлень і формуванні нових уявлень екологічної теорії. До числа принципів функціонування екосистем, здатних до самоорганізації, відносяться нелінійність, нерівноважність, незамкнутість, тобто категорії, протилежні класичній екологічній теорії. Цей напрямок спирається на досягнення теорії самоорганізації і нерівноважної термодинаміки [3], а також синергетики [4], де в якості математичного апарату досліджень використовують такі поняття, як флуктуації, фазові переходи, метастабільність, нестаціонарність, автокаталіз, авторегресії, автохвильовість, біфуркаційність, фрактали і катастрофи та ін. 


\section{Загальні відомості про синергетику та нелінійну динаміку}

Синергетика як наукова парадигма в загальній картині світу виділяє нестабільність, нестійкість i незворотність як імператив розвитку в об'єктивному світі, як головні рушійні сили в еволюції в природі. Синергетика як методологія розглядає незворотність як умову розвитку систем, а «нерівновагу» систем - як імператив розвитку, і це їі корінна відмінність від кібернетики, від теорії дослідження операцій і від загальної теорії систем. I це антиномія класичній науці, яка фетишизує стаціонарність, стійкість, оборотність. Синергетику зазвичай називають математичною діалектикою. Теорія синергетики і теорія самоорганізації, на відміну від діалектики, мають потужний апарат формалізації, набір базових і похідних моделей, у тому числі у вигляді диференціальних рівнянь в часткових похідних другого порядку, у формі фракталів з дробовою розмірністю, гамільтоніанів, що враховують передісторію і довгу пам'ять, математичних моделей, які взяті 3 теорії біфуркацій. Головний постулат синергетики як науки: «Світ розвивається (саморозвивається, самоорганізується) в результаті колективної спільної дії (взаємодії) всіх складових цього світу». Мета синергетики - виявлення загальних ідей, загальних методів і загальних закономірностей в самих різних областях природознавства.

Залучення до синергетики теорії біфуркацій Анрі Пуанкаре, теорії фракталів Бенуа Мандельброта і теорії катастроф Уїтні-Тома-Арнольда, а також узагальнення їх в органічному симбіозі в теорії самоорганізації I. Пригожина [5] надає проблемі безліч шляхів розвитку природи і новий ключ до іiі розуміння, а 3 ним - i нові можливості для прогнозування зміни навколишнього середовища. Самоорганізація відрізняється від процесу організації тим, що сутність процесу тут пояснюється вже природою самої системи (а не дією зовнішніх факторів). Тобто система є такою, що самоорганізується, якщо вона без додаткового впливу ззовні набуває певної просторової, тимчасової або функціональної структури. Самоорганізація як феномен властива також і екосистемам, які вивчає теорія синергетики. Цей напрямок все частіше позначається як екологічна синергетика (від грец.Synergetikos - спільний, узгоджено діючий) - вчення про ефекти спільних дій елементів у відкритих складних екосистемах, які підкоряються принципу «порядок з хаосу». У роботах [5-7] показано, що вплив навколишнього середовища сприяє формуванню мультиплікативних зв'язків, в результаті чого властивості узагальненої моделі екосистеми можуть принципово відрізнятися від властивостей вихідної. Отримані результати дозволяють по-новому поглянути на питання еволюції нелінійних екосистем. Через відкритість таких екосистем вони здатні обмінюватися з навколишнім середовищем речовиною, енергією та інформацією. Саме завдяки зазначеним потокам, що протікають крізь них, і відбувається самоорганізація, пов'язана зі структурною зміною екосистеми.

Тому функціонування нелінійної екосистеми необхідно описувати в рамках енергетичного балансу і з урахуванням кінетики, які відображають взаємодію компонентів, що входять в екосистему. В результаті такої взаємодії частина енергії буде витрачатись на зміну характеру їх поведінки, а інша частина - на зміну їх внутрішнього стану. У відкритій екосистемі найбільш важливим стає баланс між припливом енергії ззовні і віддачею іiі в зовнішнє середовище. 
Екосистема буде здатна проявляти стійкість і підтримувати енергетичний баланс за рахунок змін, що відбуваються в ній, одні з яких спрямовані на поглинання, а інші - на віддачу енергії. Зміна балансу енергії може привести до того, що екосистема реагуватиме на це будь-якою зміною свого структурного стану: вона або буде створювати нові зв'язки, або знищувати їх. Самоорганізація екосистеми відбувається навіть в разі агресивності оточуючого екосистему середовища. В останньому випадку екосистема мобілізується (самоорганізується) для вчинення опору. Самоорганізація екосистеми може відбуватися в результаті фазового переходу. Механізм спонтанної самоорганізації в мікрообсязі хаотичної екосистеми відповідно до ентропійного фактору може бути представлений як $\Delta S=d i S+d e S$, тобто загальна зміна ентропії визначається сумою змін внутрішньосистемної ентропії (diS) і зміною ентропії за рахунок факторів зовнішнього середовища $d e S$. При певному співвідношенні градієнта diS/deS загальна ентропія екосистеми в мікрооб'ємах може як зростати $(\Delta S>0)$, так і бути менше 0 $(d i s / d \tau<d e S / d \tau)$, і відповідно формувати новий порядок на рівні фазових переходів II роду (фазових переходів Л. Ландау). Слід зазначити, що відповідно до феноменологічної теорії фазових переходів може забезпечуватися поява нових структур. Подібно розглянутим Л. Ландау у фізиці фазових переходів, екосистема також може містити кластери двох типів: одні кластери несуть нові властивості, інші не містять нових властивостей. Під впливом зовнішніх чинників в перехідній екосистемі будуть спостерігатись кількісні зміни співвідношення між кластерами цих двох типів. Наявність двох фаз, одна 3 яких є носієм інерційної складової, а друга мутаційною, іє загальним законом розвитку нелінійних екосистем. Відповідно до принципу І. Пригожина [6] характер еволюції нелінійних екосистем визначається прагненням до зменшення ентропії, яке якраз і досягається ускладненням її структурної організації.

Формування додаткових мультиплікативних зв'язків тісно пов'язане 3 поняттям оптимальності, а також структурної пристосованості. Виходячи 3 цього, можна стверджувати, що ускладнення структури екосистеми тотожне оптимізації іiі властивостей шляхом структурної пристосованості. 3 іншого боку, в сучасній екологічній теорії все частіше стали використовувати поняття хаотична поведінка екосистем. Відомо, що «хаос» - поширена категорія міфології і філософії з часів античності, яка в XIX ст. була розвинена природничим розумінням статистичного (теплового) хаосу, а в ХX ст. - ще й уявленнями про динамічний хаос в детермінованих системах і когнітивний хаос в теорії складності. Новий підвищений науковий інтерес до проблеми хаосу викликала робота I. Пригожина, яка вийшла в 1979 році [7].

Як відомо [5], в науці «хаос» позначається терміном «турбулентність», що представляє собою надзвичайно складне, але цілком закономірне явище. Турбулентність $є$ поширеним в природі явищем самоорганізації, пов'язаним 3 регулярними або хаотичними переходами від безладдя до порядку і назад. Значний інтерес до турбулентних процесів в екологічній науці виник в 1960-х 3 появою синергетики, яку часто визначають як «науку про самоорганізацію» (мимовільне ускладнення структури екосистеми при повільній і плавній зміні iii параметрів). Поведінку динамічних екосистем в турбулентних процесах найчастіше можна описати і виходячи з поняття «переривчастої рівноваги» в теорії «самоорганізованої критичності» [8]. Відповідно до цієї теорії динамічні 
екосистеми без спеціального зовнішнього впливу приходять в якийсь критичний стан, який підтримується подіями різних масштабів. Складні екосистеми мають властивість в процесі своєї еволюції приходити до критичного стану, в якому невеликі зміни можуть сприяти розвитку ланцюгової реакції, в результаті якої екосистема опиняється в стані хаосу. У цьому стані динамічній екосистемі властива переривчаста, стрибкоподібна поведінка, яка характеризується поняттями «переривчастої рівноваги» («punctuated equilibrium»), «кризової нестабільності» («crisis instability») i «кризової стабільності» («crisis stability»), а також «катастрофи».

Поняття «катастрофа» в даному контексті означає різку якісну зміну стану в екосистемах при плавній кількісній зміні параметрів, від яких вона залежить. Однією з головних задач теорії катастроф є отримання так званої нормальної форми досліджуваної екосистеми навколо «точки катастрофи» і побудова на цій основі класифікації екосистем.

У синергетиці «хаос» оперує такими чіткими ключовими принципами $[6,7]$ :

- теорія «хаосу» додається до динамічних систем - систем з дуже великою кількістю рухомих компонентів;

- всередині цих систем існує неперіодичний порядок, зовні безладна сукупність даних може піддаватися упорядкуванню в разові моделі;

- подібні «хаотичні» системи виказують тонку залежність від початкових умов; невеликі зміни будь-яких умов на вході приведуть до дивергентних диспропорцій на виході;

- довго існуючі системи (змінні, параметри порядку та ін.) керують коротко існуючими системами.

Перераховані принципи дозволяють встановити загальні правила організації хаосу в екосистемах.

1. Хаос створюється природним шляхом за допомогою збільшення розмірів частини єдиної екосистеми, що самоорганізується, а потім, після досягнення якихось критичних меж, таким же чином гаситься.

2. Критичні межі стану екосистеми визначаються фізичними розмірами екосистеми і співвідносяться між собою експоненціальним чином.

3. Під час руху від безладу до впорядкованого стану екосистема регулярно повертається по замкнутій траєкторії дивного атрактора Лоренца навколо точки, де вона вже колись була.

4. «Масштаб хаосу», або «розмір невизначеності стану» екосистеми, пропорційний фізичним розмірам екосистеми.

5. Еволюційні фази турбулентного розвитку в екосистемах супроводжуються акумулюванням в них енергії структурної складності.

6. У точках біфуркації, навпаки, слабке зниження стійкості в екосистемі супроводжується спадом, а швидке зростання - слабким зростанням.

7. Зовнішні впливи, спрямовані на скорочення фізичних розмірів екосистеми, іiі стабілізують, а спрямовані на збільшення - дестабілізують. Тому в точках біфуркації екосистеми іiі можна легко вивести 3 рівноваги слабкими енергетичними впливами, а впорядкувати практично неможливо, тобто іiі розвиток в певні моменти проходить через так звані точки біфуркації.

8. Створюючи штучний порядок в будь-якій області замкнутого простору в екосистемах, ми переважно генеруємо хаос в оточуючих його областях (гранично нестійкий стан, в тому числі і природну нестабільність). 
Синергетика XXI століття використовує уявлення теорій самоорганізації, біфуркацій, фракталів, хаосу, катастроф і вирішує надскладні завдання прогнозування майбутніх змін в природі. Наприклад, на основі положень теорії синергетики в біології створена синергетична модель морфогенезу, що описує зародження, зростання, розвиток i смерть живих організмів 3 позитивним і негативним зворотними зв'язками. При цьому, за розвиток i мутації відповідає синергетичний позитивний зв'язок, а за збереження колишніх форм - негативний (кібернетичний) зворотний зв'язок.

На сьогодні розроблені математичні моделі міжвидової і внутрішньовидової боротьби у формі відбору за виживання і підбору, за продовження роду, зростання i розвитку популяцій в різних ареалах проживання 3 проявом якісних бар'єрів, порогових явищ, синергетичних ефектів і рефлексій. Це розвиток геномів живих організмів від найпростіших видів до найскладніших і найдосконаліших. Створена синергетична модель онтогенезу, науки про розвиток рослин і тварин з моменту зародження, яка охоплює всі зміни, трансформації та ефекти, яких зазнають живі організми від зародження до закінчення життя.

\section{Моделювання стійкості екосистеми}

Моделювання має важливу роль в описі і розумінні часових еволюцій процесів в екосистемах [9]. Математичні моделі допомагають в інтерпретації перехідних процесів в екосистемах виявити особливості їх функціонування і забезпечити прогноз: «горизонт передбачуваності», що підтверджується або спростовується подальшими даними. Для побудови математичної моделі структурних змін, що відбуваються в узагальненій моделі нелінійної динаміки екосистеми, скористаємося кінетичною теорією фазових перетворень першого роду, яка заснована на флуктуаційній картині зародження фази і подальшому зростанні эї виділень. Більшість моделей динаміки екосистем містять нелінійні функції, наприклад:

$$
y=\sin x, y=a x^{2}, z=\sqrt{x}+b y
$$

де $a$ і $b$ деякі числа, на відміну від лінійних $y=a x, z=a x+b y$ i далі, для них несправедливий принции суперпозищиї (накладення), що дозволяє «зшивати» рішення більш складного завдання 3 рішень більш простих завдань. Ці рівняння описують ситуацію, в якій зміна зовнішніх впливів в $k$ разів, на відміну від лінійних, не призведе до пропорційного відгуку екосистеми. По суті, нелінійність означає величезну різноманітність поведінки і багатство можливостей, порогові ефекти, множину рішень, існування хаотичних траєкторій, парадоксальний «антиінтуїтивний» відгук при зміні зовнішніх впливів. Розглянемо основні структури екосистеми, що відносяться до катастроф. В екосистемах під впливом внутрішніх і зовнішніх антропогенних факторів відбуваються незворотні фізико-хімічні процеси, що призводять до їх деградації. Знання змін від часу $t$ комплексного параметра життєздатності екосистеми $Y$ в залежності від небезпечних факторів $X$ дозволяє визначити значення імовірності вихідної події: 


$$
q_{i}(t)=P\left\{Y_{i}(X, T)>Y_{i г p}\right\}
$$

де $q_{i}(t)$ - імовірність вихідної події, $T$ - час існування екосистеми, $Y_{i г р}-$ граничне значення комплексного параметра стійкості екосистеми до антропогенного впливу, після якого може настати катастрофічна подія. Розглянемо сімейство функцій:

$$
E: Z C \rightarrow R
$$

де $R$ - ризик втрати життєздатності екосистеми; $Z$ - деяке різноманіття, яке зазвичай $є R^{n}$; $C$ - наслідки (збитки) від вихідної події або інше різноманіття $\left(R^{r}\right)$. В теорії катастроф простір $R^{n}$ носить назву простору станів, простір $R^{r}-$ простір управління, число $r$ - розмірність деформації. Тут під деформацією розуміються варійовані змінні. В математичному контексті (а іноді і в додатках) $R^{r}$ називається простором деформації, а його точки (або їх координати) - параметрами деформації. Дуже важливо те, що відбувається 3 функціями поблизу початку координат, бо це відбивається на поведінці функцій на всьому просторі $R^{n} \cdot R^{r}$. Підмножина $R^{n} \cdot R^{r}$, визначена рівнянням

$$
\frac{d}{d z} E_{c}(z)=0
$$

називається різноманіттям катастроф, де $E_{c}(z)=E(z, c)-$ множина всіх критичних точок потенціалів $E_{c}$ із сімейства $E$. Відображенням катастрофи $\chi$ називається обмеження на $M$ природньої проекції

$$
\pi: R^{n} \cdot R^{r} \rightarrow R^{r}, \quad \pi(x, c)=c .
$$

Особливою множиною $Z$ називається підмножина $M$, що складається 3 особливих точок відображення $\chi$ - точок, де ранг похідної $\frac{d x}{d \chi}$ менше, ніж $r$. Образ особливої множини $\chi(Z)$ з $C$ носить назву біфуркаційної множини $B$ (рис. 1).

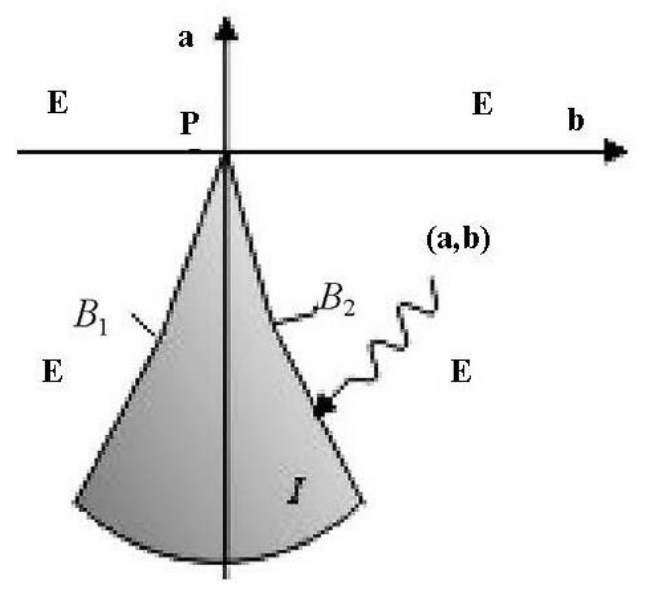

Рис. 1 - Геометрична інтерпретація рівноваги в екосистемах 
Розділимо площину $a b$ (рис. 1) на п'ять підмножин: заштриховану область $I$ - від слова internal - «всередині» кривої; область $E$ - від слова external - «поза» кривою; дві гілки $B_{1}$ і $B_{2}$ кривої від слова bifurcation (біфуркація) і початок $P$. Точки $(a, b)$, що лежать в області $I$, характеризуються рівнянням, а точки, що лежать в області $E$, умовою. Тому, якщо точка $(a, b)$ лежить в області $E$, то $\epsilon$ один дійсний корінь; якщо точка $(a, b)$ лежить в області $I$, то є три різних дійсних корені; якщо точка $(a, b)$ лежить на кривих $B_{1}$ і $B_{2}$, то є три дійсних корені, але два 3 них збігаються між собою; для $B_{1}$ збіг відбувається $з$ найменшим коренем, а для $B_{2}-3$ найбільшим; якщо точка $(a, b)$ збігається з $P=(0,0)$, тобто $a=b=0$, то є три співпадаючих дійсних корені і всі вони рівні 0. Один мінімум, якщо $(a, b) \in E$; два мінімуми і один максимум, якщо $(a, b) \in I$; один мінімум і одна точка перегину для $(a, b) \in B_{1}$ або $B_{2}$ і один мінімум для $(a, b)=P$. Біфуркаційна множина катастрофи в екосистемах - це множина точок.

$$
(a, b)=\left(-3 z^{2}, 2 z^{3}\right)
$$

Для заданої пари параметрів рівняння $(a, b)$ критичні точки функції енергії

$$
E_{a b}(z)=\frac{1}{4} z^{4}+\frac{1}{2} a z^{2}+b
$$

можна знайти з рівняння:

$$
0=\frac{d}{d z} E_{a b}(z)=z^{3}+a z+b .
$$

Дроби в коефіцієнтах підбираються таким чином, щоб рівняння (6) і (8) виходили найпростішого виду. Кубічне рівняння по х має найбільше три i найменше один дійсний корінь. Природа коренів залежить від значень $a$ і $b$, а саме від дискримінанту $D=4 a^{3}+27 b^{2}$ рівняння (8). Добре відомо, що якщо $D<0, \epsilon$ три різних дійсних корені, а якщо $D>0$, то один дійсний і пара взаємносполучених комплексних коренів. При $D=0$ є три дійсних корені, але деякі 3 них збігаються між собою: якщо $D=0$ і $a \neq 0$ або $b \neq 0$, то збігаються два корені, а якщо $D=0$ і $a=b=0$, то збігаються всі три корені. Геометрично це означає, що природа коренів, а значить і рівновага системи, залежить від положення точки $(a, b)$ відносно до кривої, визначеної в координатах $a, b$ рівнянням:

$$
4 a^{3}+27 b^{2}=0
$$

3 точки зору динаміки мінімуми $E_{a b}$ відповідають стійким рівновагам в екосистемах, а максимуми і перегини - нестійким. Отже, якщо пара керуючих змінних $(a, b)$ екосистеми лежить в області $E$, то $\epsilon$ єдине положення стійкої рівноваги, а якщо в області $I$, то два стійких стану і один нестійкий. В теорії катастроф [10] показано, що $Z$ - це множина точок $(z, c)$ з $M$, в яких $E_{c}(z)$ має вироджену критичну точку. Таким чином, $B$ являє собою місце, де змінюється число і природа критичних точок і така зміна може відбутися лише при переході через вироджену критичну точку. Слід зазначити, що в більшості додатків теорії катастроф найбільш важливим є саме біфуркаційна множина, 
так як вона лежить в просторі управління і відповідно «спостерігається», бо всі стрибки відбуваються на ній. Але в залежності від того, яке конкретне застосування розглядається, аналізується більше або менше геометричних характеристик катастрофи. Дослідження положень рівноваги саме по собі не може визначити, де будуть відбуватися стрибки в екосистемах, так як вони в принципі можливі в будь-якій точці $(a, b)$, над якою лежать два або більше положень рівноваги. Уявімо собі екосистему, що залежить від факторів антропогенного впливу на неї. Чим більше вплив антропогенних факторів на екосистему, тим менш стійкий іiі стан аж до катастрофічного стрибка. Таке значення параметра стану екосистеми називають точками розгалуження або точками біфуркації. Типова біфуркаційна діаграма, що допускає наочну інтерпретацію процесів, які відбуваються в екосистемах, і включає різні траєкторії, наведена на рис. 2.

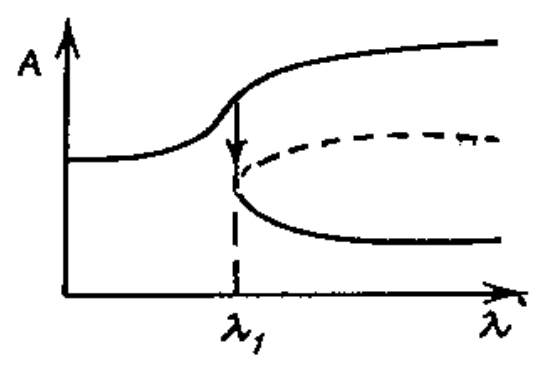

Рис. 2 - Біфуркаційна діаграма, що допускає наочну інтерпретацію процесів, які відбуваються в екосистемах, і включає різні траєкторії

Тут суцільна лінія відповідає стійкому стану екосистеми, а пунктирна нестійкому, який може змінюватися під впливом антропогенних навантажень.

Визначити момент переходу екосистеми зі стійкої рівноваги в нестійкий стан, іменований далі як «катастрофа» (стрибок), дуже складно. Геометрично це показано на рис. 3. Точка $P$ характеризує поведінку екосистеми в точці, де рівновага змінюється зі стійкої (локальний мінімум енергії) на нестійку (локальний максимум).

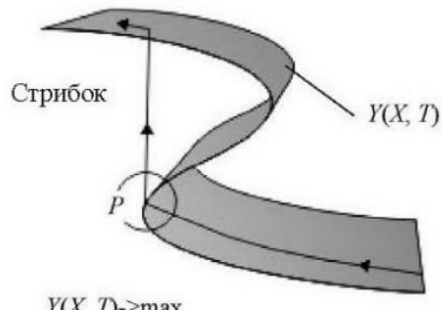

a

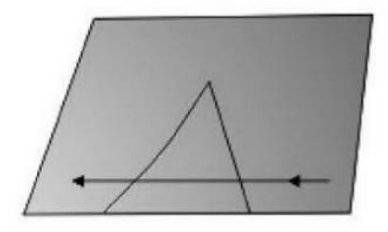

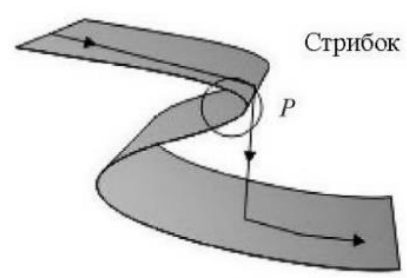

б

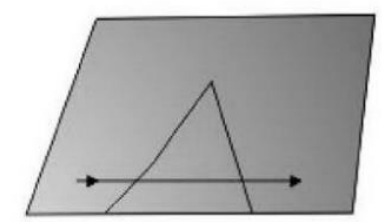

Рис. 3 - Стрибок стійкості екосистеми: a - зростаючий; б - регресний характер параметра $Y(X, T)$ 
Згідно з принципом (максимального) зволікання: екосистема робить стрибок лише тоді, коли у неї не залишається іншого вибору. Однак при цьому необхідно враховувати наступний факт: екосистема може робити відповідні стрибки настільки швидко, що дозволяє знехтувати часом, який витрачається на це. Отже, при цьому для швидких змін регулюючих параметрів принцип зволікання порушується, тобто для кожної конкретної екосистеми в залежності від дії факторів, що збурюють, можливі різні моменти порушення стану рівноваги, які можуть призвести до катастрофи. Розглянутий тип катастрофи в екосистемі $\epsilon$ найпростішим видом катастроф. Залежно від кількості i складності критичних точок поверхні різноманіття катастроф істотно ускладняється аналіз рівнянь енергії $E$. Ілюстрацією цього може служити катастрофа хвоста ластівки, метелика, еліптичної, гіперболічної і параболічної омбілік. Одним 3 фундаментальних результатів нелінійної динаміки $\epsilon$ усвідомлення принципових обмежень в області отримання прогнозу, так званого «горизонту передбачуваності», навіть для найпростішої екосистеми, оскільки вона має чутливість до початкових даних. Тобто, розглядаючи дві близькі траєкторії $\vec{x}$ '(t) $\vec{x} ”(\mathrm{t})$ в динамічній екосистемі, отримаємо

$$
d \overrightarrow{\vec{x}}=\vec{f}(\vec{x}), \quad \vec{x},(0)=\mathrm{a}, \quad \vec{x}{ }^{\prime \prime}(\mathrm{t})=\vec{a}+\mathrm{E}
$$

Для безлічі моделей екосистем можна чисельно перевірити, а для деяких випадків строго довести, що відстань між нескінченно близькими спочатку траєкторіями в середньому експоненціально зростає

$$
\mathrm{d}(\mathrm{t})=\left|\vec{x}^{\prime}(\mathrm{t})-\vec{x}^{\prime \prime}(\mathrm{t})\right| \sim|\mathrm{E}| \exp (\mathrm{lt})
$$

Величина 1, звана показником Ляпунова, що характеризує горизонт передбачуваності - час, на який можна дати прогноз поведінки досліджуваної екосистеми. Слід зазначити, що «клубок траєкторій» в екосистемах буде виглядати досить впорядкованим (рис. 4).

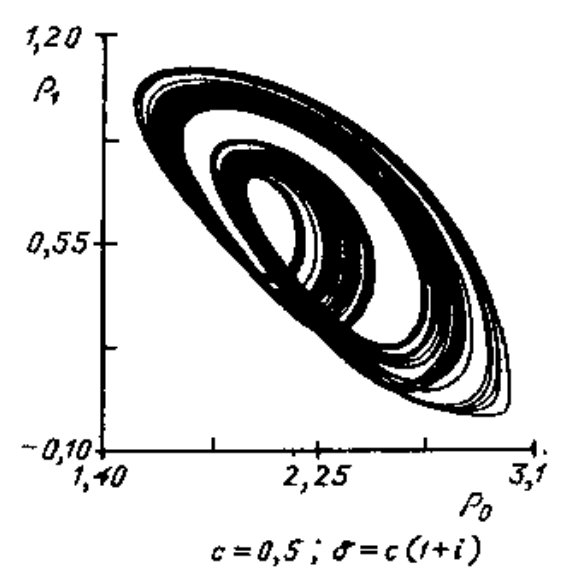

Рис. 4 - Характерний вид проекції хаотичного атрактора в екосистемах 
Зрозуміло, що це не означає, що після цього часу ми нічого не знаємо про екосистеми. Образно кажучи, якщо гранична множина являє собою «клубок» у фазовому просторі (див. рис. 4), то ми як і раніше достовірно знаємо, що точка, яка характеризує стан екосистеми, належить цьому «клубку», а не піде куди-небудь в іншу область фазового простору. Однак невідомо, в якому місці «клубка» буде знаходитися ця точка. «Горизонт передбачуваності» можна трактувати й інакше. Він дає характерний часовий масштаб, який визначає, коли (в які часи) відіб'ються зміни початкових даних на величину $E$. Він також показує, наскільки швидко екосистемою будуть «забуті» наслідки зовнішніх і внутрішніх впливів, якщо ми можемо змінити стан останньої на $E$. По суті, горизонт прогнозу характеризує «пам'ять» досліджуваної екосистеми.

\section{Висновки}

3 аналізу численних джерел інформації та наведених у даній роботі міркувань щодо моделювання еволюції реальних нелінійних екосистем в сучасних умовах можна зробити висновки, головні з яких такі.

- Умови критичного стану довкілля і великого ризику виникнення надзвичайних екологічних ситуацій i катастроф в країні вимагають застосування нового математичного апарату дослідження нелінійних екосистем, використовуючи такі поняття, як синергетика, флуктуації, фазові переходи, метастабільність, нестаціонарність, автокаталіз, авторегресії, автохвильовість, біфуркації, фрактали і катастрофи.

- На відміну від традиційних моделей, запропоновано моделювати адаптивні зворотні зв'язки в екосистемах за допомогою теорії синергетики, що дало змогу здійснювати динамічну перебудову структури екосистеми (атракторів, інваріантних різноманіть), які забезпечують множинну стійкість екосистеми з підвищенням її складності.

- Дана методологія відповідає відомим фактам про зростання стійкості екологічних систем з підвищенням їх складності й видової різноманітності.

\section{СПИСОК ЛІТЕРАТУРИ}

1. Хакен Г. Синергетика / Г. Хакен; пер. с англ. В.И. Емельянова; под ред. Ю.Л. Климонтовича, С.М. Осовца. - Москва: Мир, 1980. - 403 с.

2. Хакен Г. Синергетика. Иерархия неустойчивости в самоорганизующихся системах и устройствах: пер. с англ. / Г. Хакен. - Москва: Мир, 1985. - 421 с.

3. Гленсдорф П. Термодинамическая теория структуры, устойчивости и флуктуаций / П. Гленсдорф, И. Пригожин; пер. с англ. Н.В. Вдовиченко, В.А. Онищука; под ред. Ю.А. Чизмаджева. - Москва: Мир, 1973. - 280 с.

4. Хакен Г. Информация и самоорганизация. Макроскопический подход к сложным системам / Г. Хакен; пер. с англ. Ю.А. Данилова, А.В. Беркова. - 2-е изд., доп. Москва: КомКнига: УРСС, 2005. - 245 с. - (Синергетика: от прошлого к будущему).

5. Пригожин И. Порядок из хаоса. Новый диалог человека с природой / Пригожин И., Стенгерс И.; пер. с англ. Ю.А. Данилова; общ. ред. В.И. Аршинова, Ю.Л. Климонтовича, Ю.В. Сачкова. - Москва: Прогресс, 1986. - 432 с.

6. Николис Г. Познание сложного. Введение / Г. Николис, И.Р. Пригожин; пер. с англ. В.Ф. Пастушенко. - Москва: Мир, 1990. - 342 с.

7. Пригожин И. Время, хаос, квант / Пригожин И., Стенгерс И. - Москва: Прогресс, 1994. $-272 \mathrm{c}$. 
8. Эткинс П. Порядок и беспорядок в природе / П. Эткинс; пер. с англ. Ю.Г. Рудого. Москва: Мир, 1987. - 224 с.

9. Азаров С.I. Моделювання стійкості екосистеми / Азаров С.І., Задунай О.С. // Екологічні науки. - 2018. - № 4 /2018 (23). - С. 5-9.

10. Арнольд В.И. Теория катастроф / В.И. Арнольд. - 3-е изд., доп. - Москва: Наука, 1990. $-127 \mathrm{c}$.

Стаття надійшла до редакиії 10.04.2019 і прийнята до друку після рецензування 07.05.2019

\section{REFERENCES (TRANSLATED AND TRANSLITERATED)}

1. Khaken G. Sinergetika [Synergetics]. Moscow: Mir, 1980, 403 p. (in Russian).

2. Khaken G. Sinergetika. Ierarkhiya neustoychivosti v samoorganizuyuschikhsya sistemakh i ustroystvakh [Synergetics. Hierarchy of instability in self-organizing systems and devices]. Moscow: Mir, 1985, 421 p. (in Russian).

3. Glensdorf P. and Prigozhin I. Termodinamicheskaya teoriya struktury, ustoychivosti i fluktuatsiy [Thermodynamic theory of structure, stability and fluctuations]. Moscow: Mir, 1973,280 p. (in Russian).

4. Khaken G. Informatsiya i samoorganizatsiya. Makroskopicheskiy podkhod k slozhnym sistemam [Information and self-organization. Macroscopic approach to complex systems]. 2-d edition. Moscow: KomKniga, URSS, 2005, 245 p. (in Russian).

5. Prigozhin I. and Stengers I. Poryadok iz khaosa. Novy dialog cheloveka s prirodoy [Order out of chaos. The new dialogue between human and nature]. Moscow: Progress, 1986, 432 p. (in Russian).

6. Nikolis G. and Prigozhin I.R. Poznanie slozhnogo. Vvedenie [Knowledge of the complex. Introduction]. Moscow: Mir, 1990, 342 p. (in Russian).

7. Prigozhin I. and Stengers I. Vremya, khaos, kvant [Time, chaos, quantum]. Moscow: Progress, 1994, 272 p. (in Russian).

8. Etkins P. Poryadok i besporyadok v prirode [Order and disorder in nature]. Moscow: Mir, 1987, 224 p. (in Russian).

9. Azarov S. and Zadunaj O. (2018). Modeling of ecosystem sustainability. Ekolohichni nauky, № 4 (23), 5-9. (in Ukrainian).

10. Arnol'd V.I. Teoriya katastrof [Catastrophe theory]. 3-d edition. Moscow: Nauka, 1990, 127 p. (in Russian).

The article was received 10.04.2019 and was accepted after revision 07.05.2019

\section{Азаров Сергій Іванович}

доктор технічних наук, старший науковий співробітник, провідний науковий співробітник Інституту ядерних досліджень НАН України

Адреса робоча: 03680 Україна, м. Київ, пр-т Науки, 47

e-mail: azarov@kinr.kiev.ua

ORCID ID 0000-0002-9951-8867

\section{Задунай Олексій Сергійович}

здобувач наукового ступеня кандидата технічних наук, начальник центру Державного науково-дослідного інституту спеціального зв'язку та захисту інформації

Адреса робоча: 03142 Україна, м. Київ, вул. М. Залізняка, 6

e-mail: a.zadunaj@gmail.com

ORCID ID 0000-0001-8589-1604 